\title{
橈骨遠位骨端線損傷の一例
}

\author{
琉球大学医学部整形外科 \\ 渡慶次 学・金 谷 文 則 \\ 普天間 朝 上・茨 木 邦 夫
}

\author{
Resection of Bone Bridge at Distal Radial Epiphysis \\ after Intra-articular Comminuted Fracture \\ - A Case Report - \\ by
Manabu Tokeshi, Fuminori Kanaya, Chojo Futenma and Kunio Ibaraki \\ Department of Orthopedic Surgery, School of Medicine, \\ University of the Ryukyus, Okinawa Japan
}

\begin{abstract}
We report a case in which a bone bridge was formed at the distal radial epiphysis after an intra - articular comminuted fracture. The patient was a 7 year-old boy who sustained a comminuted intra-articular fracture (epiphyseal injury) to his left distal radius after falling from a height of 4 meters'. He received closed reduction and percutaneous pinning. He showed a malunited intraarticular fracture and bone bridge formation at the distal radial epiphysis on his first visit to our clinic. Before surgery, the ROM of the left wrist was $15^{\circ}$ in extension and $30^{\circ}$ in flexion. X-p films revealed the malunited intra-articular fracture with bone bridge at the distal radial epiphysis. There was no radio-lunate motion on $\mathrm{X}-\mathrm{p}$ films and intra-articular adhesion of the radio-lunate joint was suspected by arthrogram. We corrected the malunited intra-articular fracture by reducing malunited fragments with resection of the bone bridge and a succeeding free fat graft. One year after surgery, growth of the distal radial epiphysis was $4 \mathrm{~mm}$ in the left radius and $5 \mathrm{~mm}$ in the right. Two years after surgery, extension improved to $55^{\circ}$ and flexion improved to $70^{\circ}$.
\end{abstract}

Key words : growth plate injury (骨端線損傷), Salter-Harris type 4 (ソルターハリス 4 型), bone bridge (骨橋), malunion of intra-articular fracture (関節内骨折変形治癒), fat graft (脂肪移植)

はじめに

Salter-Harris（以下 S-H）４型の骨端線損傷は， 成長障害を起こす可能性が高く, 整復操作が必要であ る. 今回, S-H4 型骨端線損傷を伴う手関節内骨折後, 骨端線に bone bridge を形成した変形治瘾例に対し て, bone bridge を切除し，骨片を整復した後に骨端 線欠損部に脂肪移植を行い良好な結果を得たので報告 する.
症例

\section{7 才，男児}

主訴 : 左手関節可動域制限及び握力低下

現病歷 : 平成 6 年 4 月 15 日, 約 $4 \mathrm{~m}$ の高さより自 転車ごと転落し受傷した。近医にて左 S-H4 型橈骨遠 位骨端線損傷を伴う手関節内骨折, 右 S-H2 型橈骨遠 位骨端線損傷と診断され徒手整復を受けた。右側は良 好な整復が得られたものの左側は整復不十分だったた 

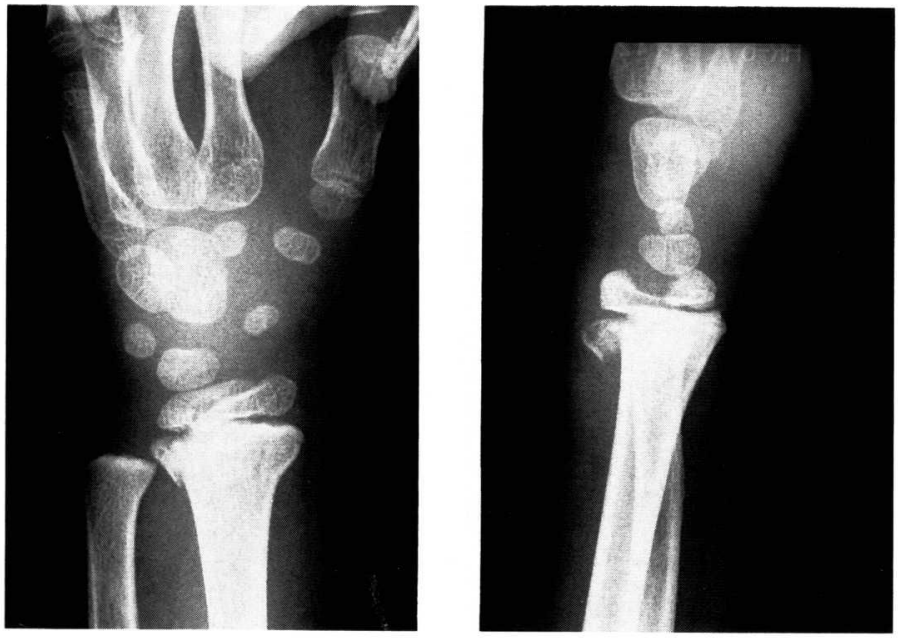

図 1 受傷時 X線像 左橈骨遠位骨端線の尺背側及び橈側に Salter-Harris 4 型の骨 端線損傷，関節中央部に陥没骨片を伴う関節内骨折を認める.

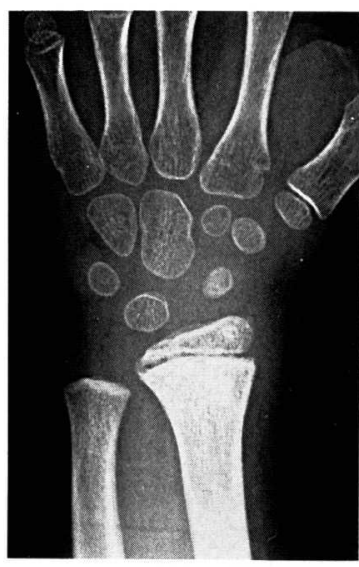

A

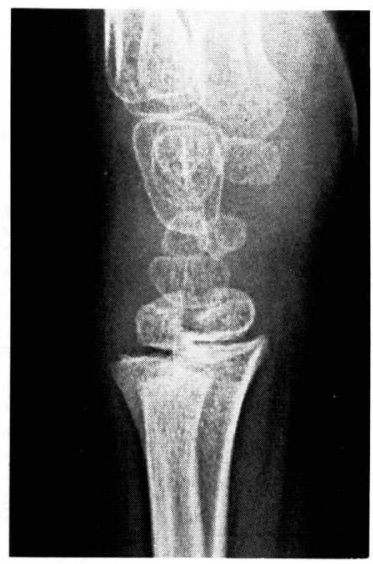

B

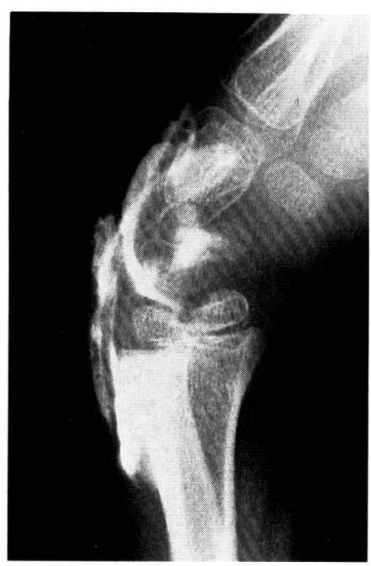

C

図 2 初診時 $\mathrm{X}$ 線像 (ピンニング後 2 力月)

A. 前後像. 橈骨中央から尺側にかけて bone bridge 形成を認める.

B. 側面像. 橈骨遠位骨端核は分離し，分離部の骨端線に bone bridge を認める.

C. 関節造影像. 骨端線損傷部で造影剂の途絶を認める.

め, 4 月 22 日，左橈骨に対し経皮的ピンニングと 9 週間のギプス固定を受けた，右側は良好な骨癒合と手 関節可動域を得たが，左側はX線上左橈骨遠位骨端線 に bone bridge 形成と手関節の可動域制限を認めた ため， 7 月 4 日当科紹介となった.

理学的所見: 可動域は, 左手関節伸展 $15^{\circ} /$ 屈曲 $30^{\circ}$, 左前腕回外 $80^{\circ} /$ 回内 $60^{\circ}$, 握力は, 左 $4 \mathrm{~kg}$ （右 $10 \mathrm{~kg}$ ）と左手関節の伸展屈曲制限と握力低下が著明 であり,さらに軽度の回内制限を認めた。

受傷時 X線像 : 左橈骨遠位骨端線の尺背側および橈 側に S-H4 型の骨端線損傷を, 関節中央部に陷没骨片 を伴う関節内骨折を認めた（図 1 ). 

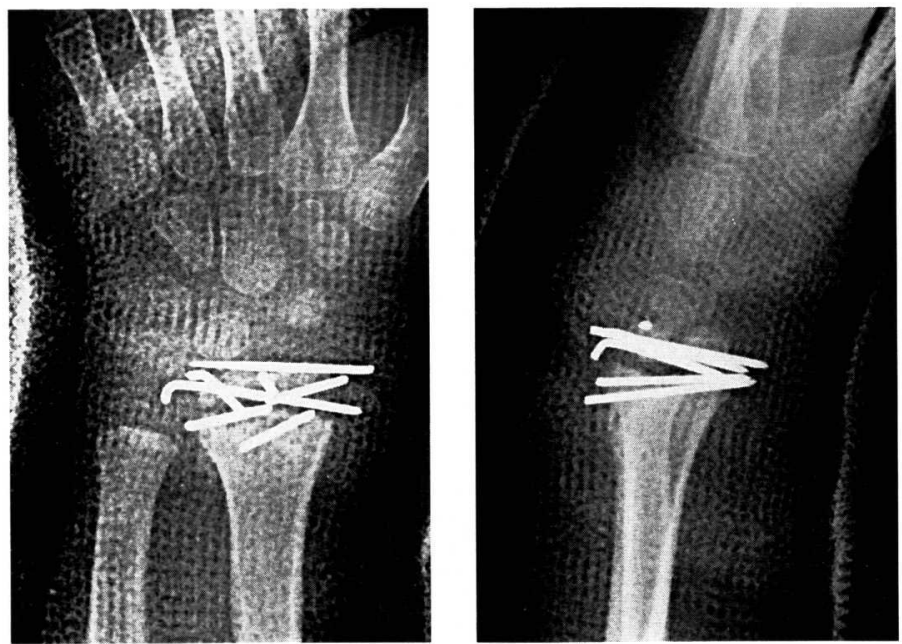

図 3 術直後 X線像

尺背側・橈側・掌側及び中央の宿没した 4 骨片を 7 本のキルシュ ナー鋼線で整復固定.
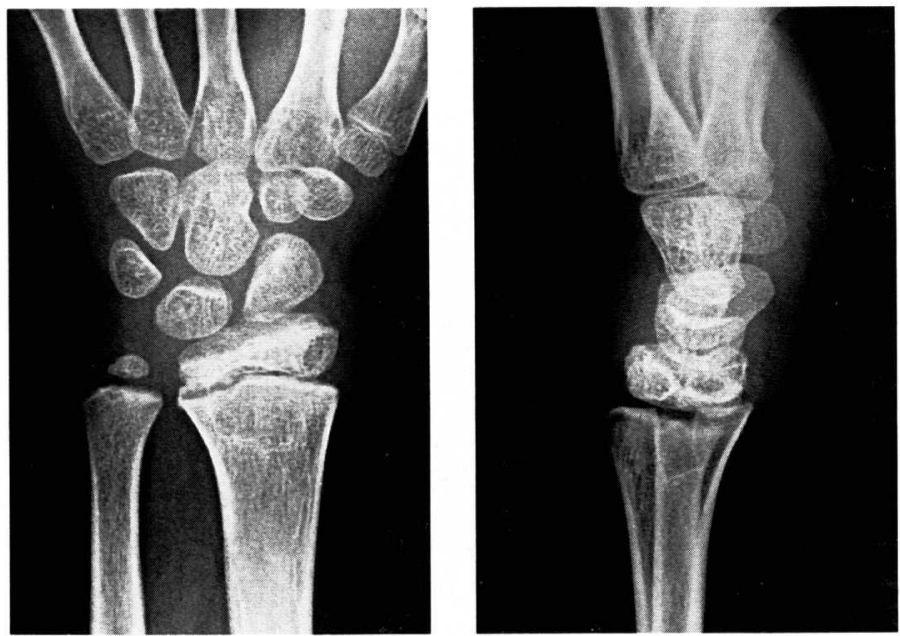

図 4 術後 X線像

術後 2 年で，骨端線に bone bridge 形成を認めない

当科初診時（ピンニング後 2 力月）：X線側面像で 橈骨遠位骨端核は分離し，分離部の骨端線にbone bridge を認めた（図 2 ).

関節造影像：骨端線損傷部で造影剤の途絶があり, 動態撮影で橈骨月状骨間の運動を認めなかった.

手術 : 変形治癒した骨幹端骨折部より bone bridge に向けて骨切りを行い, bone bridge を切除した. 橈
骨遠位端は，尺背側・橈側・掌側および陥没した中央 の 4 骨片に分加れ，中央陥没骨片の骨端線は挫滅され ていた. Bone bridge 切除後の骨端線欠損部及び中央 陥没骨片の骨端線挫隇部には前腕背側より採取した脂 肪を移植した. 整復した 4 骨片を 7 本のキルシュナー 鋼線で固定した（図 3 ).

術後経過 : 術後 2 年で手関節は伸展 $55^{\circ} /$ 屈曲 $70^{\circ}$ と 
伸展・屈曲とも $40^{\circ}$ 改善し，握力も術前 $4 \mathrm{~kg}$ から $12 \mathrm{~kg}$ (右 $13 \mathrm{~kg}$ ) へ之改善した.X線像では, 骨端線 に bone bridge 形成は見られず，手関節伸展・屈曲 で橈骨月状骨間の良好な運動を認めた（図 4 ）。橈骨 の長軸成長は $\mathrm{H} 7$ 年 8 月から $\mathrm{H} 8$ 年 8 月にかけて, 左 $4 \mathrm{~mm}$, 右 $5 \mathrm{~mm}$ であった.

\section{考察}

S-H4 型の橈骨遠位骨端線損傷は稀であるが成長障 害を起こす可能性が高く, 解剖学的整復が必要である. 転位した骨片の変形治瘉により骨端線に生じた bone bridge の治療として, bone bridge 切除のみでは再 発の頻度が高いため Bright ${ }^{11}$ は大腿骨遠位骨端線損 傷モデルで bone bridge 切除後にシリコンを移植し, bone bridge 再発と骨変形を予防できることを実験的 に証明した．臨床的には Langenskiöld ${ }^{3)}$ が大腿骨遠 位骨端線や脛骨近位及び遠位骨端線の bone bridge に対してこれを切除後に脂肪を移植し，31 例中 24 例 に関節面の変形を予防し骨切り術や骨延長術を免れ, 骨端部之関節軟骨の正常発達を認めたと報告している. 橈骨遠位骨端線損傷に関してはHorii ら ${ }^{2)}$ が bone bridge 切除後に脂肪を移植し，短期成績であるが手
関節变形の矯正が得られた 2 例を報告している.

私達は上記報告のうち異物であるシリコンの移植は 成長期の小児に不適当と考え, 本症例では bone bridge 切除後の比較的大きな骨端線の欠損に対し脂 肪移植を行い, bone bridge 再形成が予防でき, 術後 1 年ではあるが対側と同等の骨成長が得られた.

ま と め

1. 骨端線に bone bridge を形成し関節拘縮を呈 した手関節内骨折变形治癒例に対して, bone bridge 切除後骨片を整復し骨端線欠損部に脂肪移植を行った.

2. 術後良好な手関節可動域と骨成長が得られた。

\section{参 考 文 献}

1) Bright, R. W. : Operative Correction of Partial Epiphyseal Plate Closure by Osseous-Bridge Resection and Silicone-Rubber Implant. J. Bone and Joint Surg., 56 : 655-664, 1974.

2) Horii, E., et al. : Premature Closure of the Distal Radial Physis. J. Hand Surg., 18 : 11-16, 1993.

3) Langenskiöld, A. : Surgical Treatment of Partial Closure of the Growth Plate. J. Pediatr. Orthop., 1: 3-11, 1981. 